Mémoires du livre

Studies in Book Culture

\title{
Reviewers as Readers with Power
}

What a Case of Retranslation Says about Author, Translator and Reader Dynamics

\section{Arzu Eker Roditakis}

Volume 9, numéro 1, automne 2017

Le traducteur et ses lecteurs

Translators and their Readers

URI : https://id.erudit.org/iderudit/1043124ar

DOI : https://doi.org/10.7202/1043124ar

Aller au sommaire du numéro

\section{Éditeur(s)}

Groupe de recherches et d'études sur le livre au Québec

ISSN

1920-602X (numérique)

Découvrir la revue

Citer cet article

Eker Roditakis, A. (2017). Reviewers as Readers with Power: What a Case of Retranslation Says about Author, Translator and Reader Dynamics. Mémoires du livre / Studies in Book Culture, 9(1). https://doi.org/10.7202/1043124ar

\section{Résumé de l'article}

Le livre noir, deuxième roman d'Orhan Pamuk en traduction anglaise, a été publié en 1994 dans la traduction de Güneli Gün, puis dans la retraduction de Maureen Freely en 2006. La décision de retraduire a relevé surtout de l'auteur, sous l'influence de l'accueil réservé à la première traduction par les critiques, ces derniers étant les lecteurs les plus importants des traductions, puisqu'ils détiennent le pouvoir de consacrer les auteurs étrangers et leurs oeuvres dans de nouveaux lieux culturels. Le présent article propose une analyse des deux traductions anglaises du Livre noir, à la lumière de la recension critique. Il permettra de voir la manière dont les choix faits dans la première traduction ont, en quelque sorte, servi de critères pour la seconde, et de constater que les deux traductrices ont représenté l'auteur et son oeuvre différemment, surtout en raison de l'évolution du statut de Pamuk en tant qu'auteur dans le monde anglophone entre 1994 et 2006.

Tous droits réservés (C) Groupe de recherches et d'études sur le livre au Québec, 2017

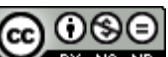




\section{MÉMOIRES DU LIVRE \\ STUDIES IN BOOK CULTURE}

\section{REVIEWERS AS READERS WITH POWER:}

\section{What a Case of Retranslation Says about Author, Translator and Reader Dynamics ${ }^{1}$}

The Black Book, Orhan Pamuk's second novel in English translation, was published in Güneli Gün's translation in 1994 and in a retranslation by Maureen Freely in 2006. The decision for retranslation was mainly taken by the author on the basis of the criticism the first translation received from the reviewers, the most significant readers of translations with their power to consecrate foreign authors and their work in their new cultural settings. This study will present an analysis of the two translations of The Black Book, taking as its point of departure the criticism expressed in the reviews. The analysis will reveal the ways in which the first translation served as a criterion for the retranslation and how the two translators represented the author and his work differently, which was mainly enabled because of the changing status of Orhan Pamuk as an author in the English-speaking world between 1994 and 2006.

Le livre noir, deuxième roman d'Orhan Pamuk en traduction anglaise, a été publié en 1994 dans la traduction de Güneli Gün, puis dans la retraduction de Maureen Freely en 2006. La décision de retraduire a relevé surtout de l'auteur, sous l'influence de l'accueil réservé à la première traduction par les critiques, ces derniers étant les lecteurs les plus importants des traductions, puisqu'ils détiennent le pouvoir de consacrer les auteurs étrangers et leurs œuvres dans de nouveaux lieux culturels. Le présent article propose une analyse des deux traductions anglaises du Livre noir, à la lumière de la recension critique. Il permettra de voir la manière dont les choix faits dans la première traduction ont, en quelque sorte, servi de critères pour la seconde, et de constater que les deux traductrices ont représenté l'auteur et son œuvre différemment, surtout en raison de l'évolution du statut de Pamuk en tant qu'auteur dans le monde anglophone entre 1994 et 2006. 
Awarded the Nobel Prize for literature in 2006, Orhan Pamuk remains to this day the most translated Turkish author as well as an established name on the world literature scene, with his work currently existing in over 60 languages. His books have been regularly translated into English since Beyaz Kale (1980) was brought out as The White Castle (1990). His latest novel, The Red-Haired Woman, came out in English in September 2017, published by Faber \& Faber. We are, therefore, speaking of a writing career in English translation spanning 27 years, during which one of Pamuk's novels was published twice. His second novel in English, The Black Book, was first published in Güneli Gün's translation in 1994 and a retranslation by Maureen Freely came out 12 years later, in 2006. This paper will focus on this interesting case of retranslation in order to explore what it offers in terms of the dynamics between the author, translators, and their readers.

\section{Retranslation in Translation Studies}

Studies and reflection on retranslation have so far followed two strands. The first is "the linear progression model," which formed the essence of the "retranslation hypothesis" as developed by Antoine Berman, Yves Gambier and Paul Bensimon in the 1990s. ${ }^{2}$ According to this hypothesis, retranslations of literary works are initiated mainly because of aging and willingness on the part of the target culture to improve the target text by bringing out its foreignness, which is assumed to have been suppressed by the first translation. Translations are thus seen in a continuum that displays an increasing level of foreignization, the first translation being the most domesticating. ${ }^{3}$

On the other hand, later case studies, which make up the second strand, have shown that readability, changing ideological and social contexts, as well as translation norms in the target culture may also be factors that bring about retranslations, and that retranslations do not necessarily tend to be less domesticating, as the initial retranslation theory assumed. ${ }^{4}$ In addition to replacing previous translations, retranslations might also aim at providing a "supplementary" interpretation, where different variations of the source text are welcome to co-exist in the target culture, as in the case of Finnish translations of Alice in Wonderland, each version of which targeted a different section of the readership. ${ }^{5}$ 
Venuti, on the other hand, offers another motive, which is that retranslations provide interpretations that challenge and compete with already existing translations. In that case, a retranslation aims at showing that the previous version is "insufficient in some sense, perhaps erroneous, lacking linguistic correctness." Here, the agency of the translator is increased as s/he aims "to bring about a new and different reception for that text in the translating culture." In all of these discussions on retranslation, the emphasis is on the receiving end. For Gideon Toury too, retranslation is an act of planning, as it "always entails some change on behalf of the receiving culture." ${ }^{8}$ Venuti goes one step further and argues that the values that retranslations bring to the target culture are "doubly domestic" when compared to translations because they are inscribed with the values of the previous translation as well as the target culture ones. ${ }^{9}$

Against this theoretical and empirical background, I think the retranslation of The Black Book might offer interesting findings and a fresh perspective on the subject. First of all, some of the motives mentioned so far can be eliminated quite readily. When it was retranslated in 2006, The Black Book had not gained the status of canonized literature in the target cultures (UK and US literary systems mainly) into which it was introduced. Therefore, it can safely be assumed that the decision to retranslate it was not based on the prestige that the novel offered, as is seen in the retranslations of canonical literature. Aging, another motive for retranslation, can also be ruled out, as the 12-year-span between 1994 and 2006 is not a long enough period for drastic changes or visible evolution to take place in the linguistic and literary norms in the target culture(s).

Since most of the conventional motives for retranslation explained above have been ruled out, the retranslation of The Black Book was a rare phenomenon in that the work of an author from a literature of lesser dissemination was retranslated into English in a span of 12 years. The case became even more worthy of scholarly attention when Pamuk revealed that it was reviewers' negative criticism that was the main motivation for retranslation. In this study, therefore, I will look at the two translations of The Black Book, exploring the ways in which this particular dynamic influenced the retranslation and the ways in which it differed from the first translation in 
terms of the reading experience the translator presented to the readership. This will be carried out by a comparative textual analysis of the translations, which will be informed by the comments in the negative reviews. I will first discuss, however, the motives for retranslation and the role that the reviewers as active agents of the publishing world play in the reception of translated literature as put forward by sociological approaches to literature and translation.

\section{Motives for the Retranslation of Kara Kitap into English}

The 2006 Faber \& Faber edition of The Black Book retranslated by Maureen Freely openly announces in its paratexts that the novel is a retranslation. On the front cover, we read that this edition is "a new translation by Maureen Freely," which is highlighted more explicitly on the back, where it is stated that "now, in Maureen Freely's beautiful new translation, the readers in English may encounter all its riches." Thus, it is implied that "Maureen Freely's beautiful new translation" is more successful in conveying the original novel's "riches" to the targeted readership. The blurbs provided on the jacket of the book are from the various reviews, which interestingly were not written for this particular retranslation:

"Dazzling . . . turns the detective novel in its head." Independent on Sunday

"A glorious flight of dark, fantastic invention." Patrick Mc Grath

"An extraordinary novel .... Up there with the best of Eco, Calvino, Borges and Marquez.' Observer 'Pamuk's masterpiece.' TLS

All published in $1995,^{10}$ these reviews pertain to the previous translation by Güneli Gün. One of them is actually written by the retranslator Maureen Freely for Gün's translation. Therefore, we can infer that the publishing house, while presenting the retranslation as enabling readers to access the "riches" of the novel, does not see any harm in benefiting from the praise that was earned by the previous translation. None of the positive comments above address Güneli Gün's translation directly. Nevertheless, Gün's contribution to such praise of The Black Book in her translation is undeniable. The publishers' deletion of her contribution while promoting the 
retranslation presents a paradox: while the retranslation is openly praised for its successful mediation, i.e. revealing the "riches" of Pamuk's text, the previous translator Güneli Gün's mediation is implicitly erased by the way the praise this translation received was used to promote the retranslation. This could be interpreted as a symptom of how literary translations are generally read in the world of publishing and how they are presented to the readership. In other words, although the novel here is presented explicitly as a retranslation, the use of excerpts praising the previous translation is a reflection of the way actors in the publishing world, namely "publishers, copy editors, reviewers," promote, in the way they treat translations, "the illusory impression" that the readers are actually reading the original. ${ }^{11}$ In this sense, while on one hand the novel is presented to the market through a different translation claimed to be better than the previous one, the use of excerpts, on the other, from the reviews of the previous translation points to the publishers' assumption that even when a different mediation is at stake, even when a different translator translates, the assessment of the translated novel will not change, as if it were the original that is read. In other words, it is taken for granted that this will not create a significantly different impact on the reading experience. Such a stance, then, is paradoxical in that it does away with the very reason for publishing a retranslation of any translated work. For publishers, what they present their readers is the unchanging essence of the novel, for which only Pamuk as the author should have the credit. On the back cover of the retranslation, the potential buyer/reader is promised a good novel in a new translation described with basic subjective formulations such as "beautiful" and "stunning." Freely's retranslation is once again mentioned inside on the first peritextual page, with reference to her earlier translations of Pamuk, which were praised by reviewers such as John Updike for being "fluent and lucid," "seamless" and "so fluent that you have to keep reminding yourself that it is a translation at all." 12 The publishers' promotional strategy to highlight such features of the translation, especially its not reading like a translation at all, confirms Venuti's argument about the "illusory impression" that I discussed above. We also learn on the same peritextual page that this new translation by Freely "replaces" Gün's translation. That is to say, the retranslation of Kara Kitap into English does not have a "supplementary nature" as suggested by Koskinen and Paloposki for various other retranslation cases; this is not a case where "variation" is welcome. Then we 
can conclude that in Pym's terms, it is an "active retranslation" in rivalry with what precedes it. ${ }^{13}$

The Vintage International edition of the novel (2006) also announces on its front cover the afterword written by the retranslator, Maureen Freely, who refers to the retranslation of The Black Book as her and Pamuk's "third collaboration" and states that the previous translation, "though ebullient and faithful to the original, was also somewhat opaque." 14 From Freely's words, we understand that as the retranslator, she aimed to clear away the perceived opaqueness of the first translation, and that the process of translation also involved the author (it being their "third collaboration"), who approved of, or rather preferred, this translational strategy. In addition, when we take into account the publisher's announcement on the peritextual page that the retranslation "replaces the previous Faber and Faber edition," we can safely state that this is a case where the first translation was "found lacking," 15 at least by Faber and Faber in England, which no longer has the book in the publications catalogue, and by the author himself, who initiated the retranslation process. Empirically speaking, however, the two translations do co-exist: while it is more difficult to get hold of Gün's translation because it is no longer promoted, one can still find it on sale in digital format and hardcover edition on amazon.com, and only in digital format on the Farrar, Straus and Giroux's website. ${ }^{16}$

It was Pamuk's decision to retranslate The Black Book and to commission Maureen Freely for this job. ${ }^{17}$ Pamuk himself described in an interview the background of his decision as follows:

Well, the only other language I have is English. But, I'm clumsy in English. Although I approved Güneli Gün's translations, they received harsh criticism, especially from England. But not only from England, from the US as well. ... But I am the person who must be committed to the representation of my books and the only language I have is English so I felt a responsibility to my books. ${ }^{18}$

An important point that Pamuk's statement suggests is that the decision for retranslation was not taken entirely due to target system dynamics, but interference from the source system. In other words, the agency of the author, 
who is aware and in control of the way he is represented in the target culture(s) (as revealed in his statement "committed to the representation of my books") also played a major role. Of course, timing is also critical in this case. It should be noted that it would have been highly unlikely for Pamuk to take the same decision before he became an established writer in the English-speaking world. In 2005, he had already had 5 novels translated into English, with My Name is Red winning the prestigious Impac Award in 2003, and he was to receive the Nobel Prize for Literature the following year, in 2006. The will and the power of the author deriving from the position he now occupies in the space called world literature can affect a decision for the retranslation of one of his novels which he deems special in his corpus in English, while most writers from minority literatures struggle to have their first translations published. In the quotation above, Pamuk implies that he cares about the presentation of his books in English, as it is the only language that he knows. This, however, certainly has to do with the current central position that the English language holds in the dissemination of world literature. Thus, Pamuk as a writer is very conscious of how he is (re)presented in the English-speaking world, which includes the important centers of world literature, i.e. London and New York. In addition, as the retranslator Maureen Freely remarks, Pamuk was also actively involved in the retranslation process, mainly because English translations were to be used as basis for translations into many other languages. ${ }^{19}$

Pamuk does not go into details in this interview, but his statements here reveal that it was indeed the dynamics of the receiving end(s) that prompted the retranslation. However, the underlying reason was not the change observed over time in linguistic, literary or translational norms, but the criticisms that the translation received in its reviews. Therefore, we can also state that the basic cause of the retranslation in this case is the presence of conflicting norms co-existing in a literary system as they appeared in reviews. However, it should be highlighted here that this essential cause might not have led to a retranslation, had the reviews not criticized the first translation explicitly and/or had Pamuk not been disturbed by these criticisms. The causal relationship between retranslation and criticisms brought against the first translation is also openly stated in "The Secrets of Kara Kitap," a volume published in Turkish that revealed secrets from the writing process of the novel, accompanied by pieces of writing and drawings by Orhan Pamuk. ${ }^{20}$ 


\section{The Black Book and its Place in Pamuk's Oeuvre as a Motive for Retranslation}

Ostensibly a detective novel, The Black Book is about the search by Galip, whose wife (and cousin) Rüya disappears along with Celâl (also his cousin), who is a columnist for a daily newspaper. Instead of taking a rational approach to his search, Galip takes on Celâl's identity, starts to live in his apartment, writes his columns and delves deep into the history and mysteries of Istanbul. The Black Book is rife with characters but one can easily say that it is Istanbul as a city that seeped into every page of the novel. Therefore, The Black Book is unique among Pamuk's novels. When the novel was published in Turkey in 1990, this was openly expressed in an interview by Pamuk himself, who stated that with Kara Kitap he could finally create the "collage" he had always wanted to, bringing together pieces of the historic past, of the present and future, stories that seem distinct and unrelated, describing the novel as "a personal encyclopaedia of Istanbul," "an attempt to embrace Istanbul as a whole with its history." ${ }^{21}$ In light of this information, it is understandable that Pamuk chose The Black Book to be presented to English-speaking readers in a retranslation, and not The New Life, his next novel in Gün's translation, which received more criticism than The Black Book from the reviewers. The timing should also be taken into account. A year before, in 2005, Pamuk's Istanbul Memories and The City had come out in English translation and it can safely be assumed that the publication of another of his Istanbul books, i.e. The Black Book in retranslation, was aimed at a combined reception through an intertextual relationship between the two books. One reviewer of Freely's retranslation states for instance that the "hüzün," the Turkish feeling of melancholy that Pamuk elaborates on in his Istanbul Memories and the City, is a key concept to understand The Black Book.22

The retranslation of The Black Book, then, is a case where reviewers, who are among the first readers of a published literary work, whether it be translation or non-translation, emerge as powerful agents in the creation of world literature. However, their role in the reception of translated literature, which has not so far been given the attention it deserves in the field of translation studies, is definitely worth a closer look. 


\section{Reviewers and Their Role in the Reception of Literature}

Book reviewers and their reviews in literary journalism matter for more than one reason. Writing and being published are necessary prerequisites for becoming a writer, but, more importantly, receiving "consecration," 23 that is, being recognized as a writer, plays a crucial role. For Pierre Bourdieu, reviewers constitute an influential group among these "agents of consecration" 24 who recognize people who write as writers. In her work that focuses on reviewing as social practice, Susan Janssen also points out the important role the reviewers and their activities play in the reception of literary fiction. ${ }^{25}$ According to this view, reviewers, along with publishers and other active agents (such as editors, literary agents and translators) in the literary system, not only act as gatekeepers in their power to determine what reaches the reading public, but also determine the context within which these texts will be read and understood. Since the second half of the 1990s, an increasing number of sociological and empirical approaches to literature have focused on reviews that were published in major newspapers and literary journals in order to explore the reception of writers. A couple of them should be mentioned because they are highly relevant to the research and findings presented here. In a study where they analyzed the publishing trajectories of 1048 writers, Ekelund and Börjesson found that being reviewed or failing to be reviewed in the New York Times Book Review had a significant effect on the future careers of the writers: those writers who achieved acknowledgement in the literary journal had longer and more successful careers. ${ }^{26}$ The results of this particular study confirm those of a previous study that van Rees and Vermunt (1996) conducted on the publishing directories of 18 Dutch writers who made their debut in the mid 1970s. ${ }^{27}$ The researchers found that receiving lengthy reviews published in "top periodicals" for their first publications was one of the main criteria that insured attention from other reviewers both for the reviewed title and the writers' subsequent works. ${ }^{28}$ These studies establish not only the fact that reviews play a major role in a writer's prospective career, but also that they are an important part of the reception process of a writer's work in a literary system. In this sense, reviewers emerge as "core agents in the symbolic production of literature." 29

The findings of these studies resonate with Johan Heilbron's sociological approach to translation, according to which the international flow of books 
is seen as constituting a "cultural world-system" as adapted from Even-Zohar's polysystem theory. ${ }^{30}$ The more central a language is in this global system, the more books will be translated from this language, which, in return, imports very little itself. ${ }^{31}$ It is an established fact that today, English is the most central language in this system, ${ }^{32}$ which makes a retranslation (such as that of The Black Book) into a language that already imports relatively little an interesting case. In a later article that they co-wrote, Heilbron and Sapiro highlight the importance of taking into account "the plurality of implicated agents" in the sociological study of translation. ${ }^{33}$ Incorporating Bourdieu's ideas on the international circulation of texts, they argue for an approach that views translation as a social practice instead of as a "purely textual" one; therefore, analyses of translations should incorporate the activities of all the agents in the field of reception, among whom critics play a significant part. ${ }^{34}$ Discussing the factors involved in the reception of a translation in a literary system other than that of its origin, Sapiro and Heilbron also quote Bourdieu's dictum that "texts circulate without their context." 35 For Bourdieu, when a text is introduced into international circulation, a series of "social operations" take place, one of which is choosing the writer who will write a preface and who will thereby inevitably "slant [the foreign] work with his own point of view." 36

Approaching literature from a systemic point of view, André Lefevere, whose main interest lay in enabling translation studies to contribute to literary theory ${ }^{37}$ rather than developing a sociology of translations in international flow, conceptualized the same phenomenon of recontextualization through the idea of "refractions" through which writers and their output are received. According to this view too, reviewers are among significant actors who refract or rewrite translated fiction for target readers. ${ }^{38}$ Another study informed by this approach looks at the ways in which the works of two Turkish authors, Orhan Pamuk and Bilge Karasu, in English translation are recontextualized in the reviews they received in the British and American target cultures. Here, the reviews are analyzed with regard to the ways they evoke issues of identity pertaining to Turkey, in other words, in terms of the "identity metonymics" they present. The resulting argument is that Orhan Pamuk's novels in English translation have enjoyed more popularity than Bilge Karasu's mainly because the reviews of Pamuk's novels link them to a broader discourse that defines Turkish cultural identity between East and West. ${ }^{39}$ 
All these studies point to the fact that reviewers, who, through their reviews, label, classify, rewrite (refract) and introduce the work to the target readership, are significant agents in the recontextualization of a translation in its new environment. And in the case of The Black Book, the criticism they voiced for Gün's translations led to the publication of the novel's retranslation in English. As a result, plausible questions could be formulated as follows: what exactly was criticized in the reviews and how were these points that were problematized by the reviewers resolved in the retranslation, if they were resolved at all? Below I will present a textual analysis of the two translations, taking as my point of departure the criticisms expressed in the reviews.

\section{COMPARATIVE ANALYSIS OF THE TRANSLATIONS}

The textual analysis in this part will be based on the reviews published in the mainstream media, in which the reviewers support their argument with at least one excerpt from the translation. The idea is that the reviewers' criticisms of Gün's translation provide fruitful starting points for comparison with the retranslation to explore in what ways they have been altered and how this difference also influences the relationship the translator establishes with her prospective readership.

\section{The Black Book as Translated by Güneli Gün in the Reviews}

Before publication, Gün's translation went through an editing process at Farrar, Straus and Giroux, Pamuk's first publisher in the US before he transferred to Knopf, which published the retranslation. Gün once stated in an interview in 1994 that this editing process had been a meticulous one and that "Orhan doesn't worry about his holy word," 40 which indicates that at the time of the publication there was no disagreement between Güneli Gün and Orhan Pamuk about the way The Black Book was translated. In the early 1990s, Pamuk was a promising young author from Turkey with only one novel published in English translation in 1990, The White Castle. ${ }^{41}$

Published in 1994 by FS\&G in the USA and by F\&F in the UK in 1995, Güneli Gün's translation received quite a few reviews in the major 
newspapers and journals in both countries: 23 reviews in total, 13 of which were published in US outlets and 10 in British outlets. ${ }^{42}$ Although some reviewers were very positive ("exciting, imaginative, intelligent" Phoebe-Lou Adams, Atlantic Monthly; "extraordinary novel" Maureen Freely, the Observer; "dazzling novel ... Orhan Pamuk as one of the freshest, most original voices in contemporary fiction" Joan Smith, The Independent), others seem to have received The Black Book with more reservation than they did Pamuk's previous novel, The White Castle. A few reviews are negative; others are mixed in that they express both positive and negative comments about the novel. For example, Robert Irwin in TLS writes, "considered as a novel, The Black, Book is a little disappointing, for it fails to deliver the conventional satisfactions. It should really be read as an encyclopaedia of esoterica and as a compendium of medieval and modern literary tricks. As such, it is quite wonderful." The most common comment in the reviews is that The Black Book is a challenging, but at the same time a rewarding read for the common reader ("demanding but engaging" Jonathan Coe, The Guardian; "It is a trying book and worth trying," Richard Eder, Los Angeles Times Book Review; "once you get past the initial difficulties, the experience is extraordinary" Dean Flower, Hudson Review). As we see in some of these excerpts, some of the aspects the reviewers criticize have more to do with the novel's structure and plot, rather than its stylistic qualities but almost all reviews agree that The Black Book is a challenging read in one way or another. In the comparative analysis below, however, those reviews that are directly relevant to Gün's translation will be singled out and their specific criticisms concerning the translation, namely those by Hugo Barnacle (The Independent) Alev Adil (TLS) and Giles Coren (The Times) will be taken as basis for comparison between the two translations.

\section{Reducing the Readers' Burden}

Published in the British newspaper The Independent in 1995, Hugo Barnacle's review of Gün's translation of The Black Book was one of the most negative, laden with lexical choices such as "high-grade tedium," "so very big and heavy," "boring," "very nasty" and even "lethal" to describe the novel. Although he does not bring up the issue of translation openly in his review, Barnacle complains of a sentence without explicitly stating what exactly is wrong with it, but it can be inferred that it is one of those sentences 
responsible for the heaviness and the tedium of the novel perceived by the reviewer:

Every time a character speaks, he/she embarks on a story or lecture, talking in paragraphs up to four pages long and in language like this: "And on those sad fall evenings when the night comes early, looking at the naked trees in the pale light from the apartment buildings, I knew that he would think of me ...."

We understand that the problem here for the reviewer is the length and the complexity of the sentence. The sentence is from Chapter 17 titled "Do You Remember Me?" in both translations. The narrator Belkis is a woman, an old classmate of Galip, whom he chanced upon on one of his adventures in Istanbul while looking for Rüya and Celâl, his wife and cousin who ran away together. Addressing Galip, whom she used to be secretly in love with, Belk1s is talking about her late husband, whom she married because she had managed to make him look at her the way Galip looked at his wife Rüya. Below is the same sentence in Gün's and Freely's translations respectively:

And on those sad fall evenings when night comes early, looking at the naked trees in the pale light that came from the apartment buildings, I knew that he would think of me the same way you thought of Rüya when you looked at those trees. ${ }^{43}$

On those sad autumn evenings when the sun sets so early and the branches look so bare in the harsh light of the apartments, I knew he'd be looking at them just like you did, but thinking of me, not Rüya. ${ }^{44}$

In the source text, in the length of one sentence we are told that the woman and her boyfriend are looking at the same trees on fall evenings at the same time, and the woman would know that her future husband would be thinking of her, the same way Galip would think of Rüya. In Gün's translation (mainly because it follows the Turkish syntax closely), the reader is at a loss as to who is the agent looking, until halfway through the sentence, i.e. until "I (knew)," which creates a strain on the reader's memory. This is probably what led the reviewer to complain about the language, as it makes the reading experience 
relatively difficult. Apart from a few other semantic changes, it is exactly because of this feature that Freely's retranslation differs from Gün's. In the retranslation, although the sentence reads as a whole without being divided by full stops, this challenge for the reader is overcome by getting rid of the participle phrase "looking at the" and the introduction of another subject + verb phrase that connects to the subordinate clause ("when"), which also causes a semantic change. In other words, in the retranslation, the woman is not looking at the trees while she is thinking; instead, the branches of the trees become the subject of the second part of the subordinate clause ("when ... the branches look so bare"). The increase in the number of subject + verb units eases the reading process as the reader is given pieces of information building up on each other in a successive manner, instead of having to keep in mind the beginning that later connects to the ending of the sentence. While Gün's translation preserves or reproduces the suspense in the Turkish version, the retranslation opts for an easier reading experience. In stylistic terms, this is the difference between "anticipatory" and "trailing constituents," which are defined by Leech and Short as follows:

Anticipatory constituents bring an element of suspense into syntax. A dependent constituent is one which cannot stand on its own, and hence cannot be interpreted in isolation. An anticipatory constituent must therefore be held in the memory until the major constituent of which it is a part has been interpreted. Trailing constituents, on the other hand, do not involve such suspense: we can interpret them as we go along. ${ }^{45}$

In this perspective, the sentence in Freely's retranslation contains "trailing constituents," whereas Gün's is based on the principle of "anticipatory constituents." Leech and Short also point out that "periodic sentences" that make use of anticipatory constituents place a burden on the reader's memory and, as such, run the risk of going against what they call "the memory principle": "Reduce the burden on the reader's immediate syntactic memory by avoiding major anticipatory constituents." 46 The Turkish syntax requires the verb to be at the end of a sentence, and because Pamuk's sentences in the Turkish source text are purposefully and notoriously long, we can safely state that the sentences in the source text contain a lot more anticipatory constituents than English grammar and syntax allow for. In the above 
example, Gün's translation follows this structure as long as the syntactic features of the English language allow, which leads the reviewer Hugo Barnacle to comment negatively on the sentence. Freely's retranslation, on the other hand, frees the reader of this burden by rendering the "anticipatory constituent" as a "trailing" one.

Another difference that attracts attention in the retranslation here is that the American "fall" has been changed to "autumn," thereby pointing to a "Britishizing" of the American English of the first translation, which was, as we will see below, another point of criticism in the reviews.

\section{Smoothing Out Lexical Bumps}

In this section, the comparative analysis will be based on two separate reviews as they both problematize Gün's lexical choices. Writing in the Times Literary Supplement, Alev Adil criticizes Gün for "bumping up Pamuk's lexicon" through lexical choices that are "colloquial and pretentious where Pamuk is not." Adil's examples to support her argument are as follows: "[Gün] translates 'sapiyla' - the stem (of a ballpoint pen)—as 'the butt end.' 'Karanllk,' which means "darkness," she burdens with the musty lyricism of 'gloaming."' Both examples Adil provides in her piece are from the second chapter "The Day the Bosphorus Dries Up," in which Celâl, Galip and Rüya's cousin, describes what it would look like if the waters of the Bosphorus receded one day. The general style of this chapter is heavily marked by apocalyptic tones, and Gün uses Latinate lexical choices in order to make this vision stronger. ${ }^{47}$ In Turkish, Pamuk uses the word "karanlik" twice in the same paragraph, and Gün does translate the first one as "darkness," but for the second "karanlık," she chooses "gloaming." 48 This could be because of her conscious strategy to avoid the repetitions that she thinks Pamuk's language suffers from, and her intention to intensify the "prophetic tone" 49 by using a word that is older and rarely used in daily language. Adil is right when she says Gün goes for the more colloquial when Pamuk's language is not. Here Adil's focus of criticism is the phrase "butt end," whereas for her it should have been translated as the "stem of a pen."

Adil's third example in her review problematizes another colloquial use in Gün's translation: the translation of "bir deri bir kemik at"50 (literally 
translated: a-skin-a-bone horse) as "a nag," instead of the more familiar "skin and bone" which Adil suggests. However, Adil makes a mistake here: Gün's translation is not "simply 'a nag," but "the skinny nag." Therefore "skin and bone" could not have been an option in Gün's translation. As is the case with most reviews that criticize translations, it is clear that Adil's criticisms present a limited view that ignores the translator's overall strategy, whereas all the lexical choices can be seen within the strategy Gün adopted for her translation: to give Pamuk's novel "a living voice in idiomatic American which is at times irreverently colloquial and at times intensely erudite-as is the original." 51 Nevertheless, it seems that it is exactly this idiomatic American in Gün's translation that is the problem here for Adil.

We do not know what Adil thinks of Freely's translation, but we see that all the points that Adil touches upon in her review have been changed in the retranslation: the "butt end" of the pen becomes "its tip," 52 "gloaming" becomes "darkness," 53 and "the skinny nag," "emaciated horse." ${ }^{4}$ As Freely herself acknowledges, there are two main differences between her retranslation and Gün's translation:

There were two areas in which [Gün] was different; one was grammatical structures, because I think of her and Orhan's shared desire to be exact. And then it was her choice [of] words in English; she was enjoying using the full range of English, whereas I found it useful to repeat words, as this approach helped me build (or rather recreate) a narrative trance. .5

In accordance with her statements above, it is observed that Freely exchanges colloquial lexical choices for more standard word choices in English and repeats "darkness."

Adil once again criticizes Gün's “clumsy” syntax and word choice in another excerpt she gives in her short piece:

For instance, her translation "after chewing him out for his failure to keep in touch, using the same tone of voice as when she scolded her cat" (as well as being clumsy) distorts the Turkish phrase which uses the same verb 
"azarlamak," whose meaning more closely approximates to "scold" or to "reproach" than "to chew out," twice. 56

The sentence that Adil criticizes reads in both translations as quoted below:

After chewing him out for his failure to keep in touch, using the same tone of voice as when she scolded her cat Coals for scratching the furniture, she told him to stop at Aladdin's store on his way to dinner and pick up some food for Vasif's goldfish: ${ }^{57}$

She berated him for ignoring her, in the same voice she used with Charcoal, her cat, when it scraped up its sharp claws against the furniture, and then she asked if he could stop by at Alaaddin's shop on the way over to pick up some food for Vasif's Japanese fish: ${ }^{58}$

Adil remarks that although Pamuk uses the same verb "azarlamak" twice here, Gün "omits this repetition" and opts for "chewing him out", which, in her opinion, is a semantic and stylistic mismatch for "azarlamak" ("to scold"). For Adil, the same sentence also suffers from clumsiness. Comparing it with the first sentence in the source text, we can see that Gün again follows the Turkish syntax and carries over the reading experience of the Turkish readers into English in terms of the "memory principle." 59 In this sense, in a similar vein to the Turkish readership, the English-speaking reader has to keep in mind all the constituents until the phrase "she told him," in order to start making sense of the sentence. In Freely's translation, on the other hand, independent sentences with $\mathrm{S}+\mathrm{V}$ grammatical structure instead of present participles are used in a succession instead of dependent clauses. The memory principle is also helped by the introduction of "then" in mid-sentence rather than at the beginning. In addition, Freely also avoids repeating the verb "scold," diverting from what Pamuk does in the original. Instead, she opts for "to berate," which is less idiomatic than Gün's "chew out."

The second review mentioned above is Giles Coren's review, which appeared in the Times. It presents a similar argument to Adil's:

Pamuk's allusive, elusive style has invited comparisons with Borges, Calvino and Marquez; but exactly how good 
he is is hard to say, so obscured is his text by the opacity of this translation. It is hard enough to get the feel of a foreign book when it is translated, but this is full-blown American: Turkish people "chew each other out," and call their parents "Mom" and "Pop." 60

Similarly, Coren also takes issue with the American idiom in Gün's translation, however for a different reason than Adil. While for Adil, Gün's stylistic choices in her translation misrepresented Pamuk in English, for Coren, who has no access to the Turkish source text, the perceived overuse of American lexical items in the translation does not match what he believes to be the appropriate way a Turkish novel should be represented in the English language. We have seen above that the verb "berate" replaces "chew each other out" in the retranslation. Likewise, "Mom" and "Pop" are also replaced by the more standard "mother" and "father" in Freely's retranslation.

It should also be noted that the reviews presented in this study are not the only ones in which criticism is voiced against Gün's translations. Her rendering of Pamuk's following novel The New Life (1997) was also criticized in a high number of reviews (out of 31 reviews, 7 voiced negative views about the translation and 3 were positive) for the same stylistic features that were problematized by the reviewers of The Black Book.

A discussion of two presumably distinct translation strategies, namely foreignization and domestication, is relevant here mainly for two reasons. Firstly, these two strategies pertain to the Retranslation Hypothesis mentioned at the beginning of the study. Secondly, pointing primarily to the reader's response to the translated text, these two strategies are also relevant in terms of the relationship the two translators establish with their targeted readership. The analysis presented in this study indicates that Freely's translation is more domesticating in terms of the fluency in syntax. As Douglas Robinson rightfully argues, fluency might be difficult to construe as "an intrinsic property of a word or phrase." 61 However, the stylistic approach implemented here through the use of the concepts of "anticipatory" and "trailing constituents" as developed by Leech and Short ${ }^{62}$ revealed that fluency in syntax can indeed be a characteristic inherent in the text and objectively verifiable. In terms of syntax, then, Freely's retranslation is more 
domesticating than Gün's, or Gün's is more foreignizing than Freely's. This being said, it is difficult to state that domestication is an overall translation strategy for Freely's retranslation, which, for instance, resorted to a more frequent use of calques/loanwords than Gün did, thereby registering the foreignness of the novel through bringing into English culture-specific terms such as "meyhane," "börek" and "Istanbullu." And considering her close collaboration with the author, could we really argue that her retranslation is merely "an ethnocentric reduction of the foreign text to receiving cultural values"? 63 Describing Gün's translation as foreignizing is also problematic, this time due to the relative nature of the strategy, immediately entailing the question: foreignizing for whom?64 In a similar vein, foreignness and familiarity are also subjective and relative. This manifests itself in the contrast between the ways some reviewers, such as Giles Coren quoted above, approach Gün's use of American idiom in her translation and the way Gün herself thinks about her strategy, which she explicates below:

Lawrence Venuti, who wants the translator rightfully recognized as the second artist, also champions "foreignizing" a text, but Venuti has the advantage of dealing with the Italian culture which is quite readily available to the Anglo-Saxon world. The world of the Turk, on the other hand, is already considered so foreign, so distant and so unavailable that further "foreignizing" that world would be keeping alive the myth (in Gladstone's words) of "the unspeakable Turk." I opted for the strategy of making that world familiar, near and available by letting Turkish characters speak idiomatic American. ${ }^{65}$

Although she considers her role as the second author in the translation process, and thus refuses to be an invisible translator, Gün nevertheless expresses her concerns about rendering the distant cultural context of the source text "familiar" to her English-speaking readership. Her solution is to use idiomatic American, which creates a foreignizing impact on the reviewers' (for instance, Giles Coren and Alev Adil's) reading experience. This points to a gap between the translator's intentions and (some of) her readers' experience of her translations, which reveals the relative nature of what is familiar/unfamiliar. ${ }^{66}$ However, although its existence must be acknowledged, we should also caution against generalizing this gap. With regard to the American idiom in Gün's translation, we do not know the 
opinion of, for instance, other reviewers who thought that Pamuk was "the freshest, most original voices in contemporary fiction" 67 or that "The Black Book offers many pleasures, Gothic, Borgesian and other," 68 both of which are praise earned by the novel in Gün's translation.

\section{Concluding Remarks}

The excerpts presented in the comparative textual analysis above reveal that the marked language criticized heavily by the critics does not appear in the retranslation. In this respect, reviewers as powerful agents in the reception of translated literature by the general readership played a role not only in the decision to retranslate, but also in the way this retranslation was carried out. Although, among Pamuk's books in English, Gün's translations were the ones that received the most criticism, this does not mean that there was full consensus among the reviewers, either. In this respect, the subjective nature of reviewing should not be overlooked. There were, for instance, British reviewers who did not voice any criticism against Gün's translation of The Black Book. As we have seen here in Alev Adil's comments on Gün's rendering of The Black Book, major criticism came with the translation of The New Life and then was extended retrospectively to The Black Book, mainly in England. Writing in Newsday, an American reviewer praised Freely's retranslation, stating that the "earlier rendition ... suffered from an arch diction and uncertainty of tone that never let you forget it was a translation." 69 The retranslation phenomenon in this case, therefore, cannot be connected to the differences in translational norms active in the US and British target literary systems.

The comparative translational analysis in this study indicates that as translators, Gün and Freely offer different reading experiences to their prospective English-speaking readership. However, it should be kept in mind that the relationship translators establish with their readers is not independent of the translators' relationship with the author and his/her status in world literature. The Black Book was Pamuk's second novel to be translated into English. When Gün and Pamuk met for the first time, Pamuk had read On the Road to Baghdad, Gün's second novel,70 and asked Gün to "give [him] that voice," 71 which became Gün's translational strategy as well. As Pamuk himself admits later on, he did not see a problem with Gün's translations at the time. ${ }^{72}$ 
Twelve years later, however, Pamuk had had five of his novels published in English, with the sixth to be published in a retranslation through his own initiative. He was actively involved in the translation process and had a clear idea of what he did not want for the representation of his novel in English. The retranslation as the outcome of such a process was bound to be different from Gün's. In the excerpts analyzed above, we have seen the retranslator transform the "heavy" sentence structure so as to ease the task of the reader and alter the lexical choices that reflect American colloquialisms into standard English, overcoming in this way the "opacity" of the translation that was pointed out in most of the reviews and answering to the perceived expectations of the general readership as well as, it should be highlighted, the requirements of the author. The retranslation of The Black Book, therefore, is a valuable case in that it clearly establishes the power that reviewers as readers and refractors of a translated work of literature can display in the reception of that work by the general readership.

Arzu Eker Roditakis has an MA degree in translation from Boğaziçi University in Istanbul, where she later became part of teaching faculty and taught courses on translation theory, practice and criticism. Currently residing in Greece, she has also lectured on translation and English writing at the American College of Thessaloniki and Aristotle University of Thessaloniki, where she completed her $\mathrm{PhD}$ dissertation on the English translations of the Turkish author Orhan Pamuk.

\section{Notes}

${ }^{1}$ My research and findings in this study are based on my $\mathrm{PhD}$ dissertation, in which I focus more comprehensively on the recontextualization of Orhan Pamuk's novels published before he was awarded the Nobel Prize in 2006. What I present here is a slightly revised and updated version of my discussions in the dissertation. I thank the two referees for meticulously reading the first version of this paper, which benefited considerably from their suggestions and criticisms.

2 Şehnaz Tahir-Gürçağlar, "Retranslation," in Routledge Encyclopedia of Translation Studies, ed. Mona Baker and Gabriela Saldanha (London and New York: Routledge, 2009), 235. 
3 Tahir Gürçağlar, "Retranslation," 233-34; Kaise Koskinen and Outi Paloposki, "Retranslations in the Age of Digital Reproduction," Cadernos de Traducao 11 (2003): 295.

${ }^{4}$ Tahir Gürçağlar, "Retranslation,” 233-34; Koskinen and Paloposki, "Retranslation,” 29596.

${ }^{5}$ Koskinen and Paloposki, "Retranslations," 22-23.

${ }^{6}$ Lawrence Venuti, "Retranslations: The Creation of Value," in Translation and Culture, ed. Katherine M. Faull (Lewisburg: Bucknell University Press, 2004), 26.

${ }^{7}$ Ibid., 29.

${ }^{8}$ Gideon Toury, "Culture Planning and Translation," in Anovar-anosar, estudios de traducción e interpretación (Vol. 1), ed. Alberto Alvarez Lugrís and Anxo Fernandez Ocampo (Vigo: Universidade de Vigo, 1999), 13-26.

9 Venuti, "Retranslations," 25.

${ }^{10}$ The TLS excerpt on the front cover is from "Tales of the City" July 7, 1995, written by Robert Irwin. The Independent Sunday excerpt is from Joan Smith's "Three Authors in Search of a Body" dated August 13, 1995. The statement by McGrath, the only reviewer in the paratexts whose name is mentioned, is from his "Dark and Fantastic Invention" published in The Washington Post, February 1995, and Maureen Freely's is from her review titled "Clues to a Maze" published in The Observer on June 25, 1995.

11 Lawrence Venuti, "How to Read a Translation," Words Without Borders (July 2004), http://wordswithoutborders.org/article/how-to-read-atranslation/\#ixzz1aIXq0qFI.

${ }^{12}$ Orhan Pamuk, The Black Book, Trans. Maureen Freely, (London: Faber and Faber, 2006), first peritextual page.

13 Anthony Pym, Method in Translation History (Manchester: St. Jerome Publishing, 1998).

${ }^{14}$ Maureen Freely, “Translator's Afterword," in The Black Book, Orhan Pamuk (London: Faber and Faber, 2006), 464.

15 Koskinen \& Paloposki, "Retranslations," 23.

16 The Black Book in Gün's translation is available and can be viewed at: https://www.amazon.com/Black-Book-Orhan-

Pamuk $/ \mathrm{dp} / 0374113947 / \mathrm{ref}=\mathrm{tmm}$ hrd swatch 0 ? encoding $=\mathrm{UTF} 8 \& q i d=\& \mathrm{sr}=$ and https://us.macmillan.com/theblackbook/orhanpamuk/9781466887633/, accessed September 30, 2017

${ }_{17}^{17}$ Michael McGaha, Autobiographies of Orban Pamuk (Salt Lake City: University of Utah Press, 2008), 119.

18 Orhan Pamuk, “The Melancholy Life of Orhan Pamuk," Interview by Joy E. Stocke, Wild Review (Winter 2006), http://www.wildriverreview.com/1/wnt2006-spotlight pamuk.html. 
${ }^{19}$ Maureen Freely, "Literary Translation is a Literary Thing," Interview by Duygu Tekgül. Ceviribilim 04 (May-June 2011): 5; Pamuk, "Melancholy,” 2006.

20 "Kara Kitap was published in English in two translations. The first of these was Güneli Gün's. Because of the criticisms that this translation received, Kara Kitap was translated years later for the second time, by Maureen Freely." Darmin Hadzibegovic and Orhan Pamuk, Kara Kitap'in Sirlar Orhan Pamuk'un Yaz ve Resimleriyle (The Secrets of Kara Kitap with Writings and Drawings by Orhan Pamuk), (Istanbul: Yap1 Kredi Publications, 2013), 119. [My translation].

21 Orhan Pamuk, Öteki Renkler: Seçme Yą̨lar ve Bir Hikaye (Istanbul: İletişim Publishing, 2006 [1999]), 139. [My translation].

${ }^{22}$ Scott McLemee, Review of The Black Book, “One City's Melancholy," Newsday (July 23, 2006).

${ }^{23}$ Pierre Bourdieu, The Field of Cultural Production, Ed. Randal Johnson (Cambridge: Polity Press, 1993).

${ }^{24}$ Ibid., 121

25 Susan Janssen, "Reviewing as Social Practice: Institutional Constraints on Critics' Attention for Contemporary Fiction," Poetics 24 (1997): 275-76.

${ }^{26}$ Bo G. Ekelund and Mikael Börjesson, "The Shape of the Literary Career: An Analysis of Publishing Trajectories," Poetics 30 (2002): 341-64.

${ }^{27}$ Kees van Rees and Jeroen Vermunt, "Event History Analysis of Authors' Reputation: Effects of Critics' Attention on Debutants' Careers," Poetics 23 (1996): 317-33.

${ }^{28}$ Ibid., 325, 332.

29 Pauwke Berkers, Susanne Janssen and Marc Verboord, "Contra-flows in Literary Journalism? Coverage of Foreign, Non-Western and Ethnic Minority Literatures in French, German, Dutch and American Newspapers, 1955-2005," in The Invasion of Books in Peripheral Literary Fields: Transmitting Preferences and Images in the Media, Networks and Translation, ed. Petra Broomans and Ester Jiresch (Groningen: Barkhuis, 2011), 25.

30 Johan Heilbron, "Towards a Sociology of Translation: Book Translations as a Cultural World System," European Journal of Social Theory 2, no. 4 (1999): 429, 440.

${ }^{31}$ Ibid., 438-39.

32 Ibid., 433-34.

33 Johan Heilbron and Gisele Sapiro, "Outline for a Sociology of Translation," in Constructing a Sociology of Translation, ed. Michaela Wolf and Alexandra Fukari (Amsterdam, Philadelphia: John Benjamins Publishing, 2007), 94.

Vol. 9, n 1 | Fall 2017

"Translators and their Readers" 
${ }^{34}$ Ibid., 104-5.

35 Ibid., 103.

36 Pierre Bourdieu, "The Social Conditions of the International Circulation of Ideas," in Bourdieu: A Critical Reader, ed. Richard Shusterman (Oxford: Blackwell Publishers, 1999), 222.

37 André Lefevere, "Mother Courage's Cucumbers," in Translation Studies Reader, ed. Lawrence Venuti (London and New York: Routledge, 2000 [1982]), 233; André Lefevere, "Why Waste Our Time on Rewrites? The Trouble With Interpretation and the Role of Rewriting in an Alternative Paradigm," in The Manipulation of Literature, ed. Theo Hermans (London \& Sydney: Croom Helm, 1985), 215-43.

${ }^{38}$ Lefevere, "Mother Courage," 234. In his later work, Lefevere used the term "rewriting" as a more comprehensive category to refer to all derivative texts "that rewrite the actual text in one way or another, such as plot summaries in literary histories or reference works, reviews in newspapers, magazines, or journals, some critical articles, performances on stage or screen, and, last but not least, translations." André Lefevere, Translating Literature (New York: The Modern Language Association of America, 1992), 6-7. Emphasis mine. However, clustering the reception texts of the original works and of the translations all in the same ontological category lacks methodological precision and it erases the mediation, in Lefevere's terms, the "refraction" produced by the translation in between. Reviews of translations, in my opinion, should be seen as refractions of a previous refraction, i.e. the translated work itself. Nevertheless, Lefevere's work is unarguably ground-breaking mainly because it emphasizes the need for the study of the social and cultural context literary works are embedded in and provides a conceptual framework for its analysis, of which, as he puts it in the above quotation, "reviews in newspapers" are a significant part.

${ }^{39}$ Arzu Eker Roditakis, "The Identity Metonymics of Translated Turkish Fiction in English: The Cases of Bilge Karasu and Orhan Pamuk," in Tradition, Tension and Translation in Turkey, ed. Şehnaz Tahir Gürçağlar, Saliha Paker, and John Milton, (Amsterdam \& Philadelphia: John Benjamins, 2015), 273-96.

40 Gün quoted in Judy Stone, "Orhan Pamuk: Enigma is Sovereign." Publishers Weekly (December 19, 1994): 36-37.

${ }^{41}$ Pamuk's first novel to appear in translation, The White Castle was translated by Victoria Holbrook and published in the UK by Carcanet Press (1990) and George Brazilier (1991) in the US. Therefore, The Black Book was the first Pamuk novel that Gün translated into English, to be followed by The New Life, which was the last Pamuk novel that was published in Gün's translation.

42 To be more precise, around the time it was published, The Black Book in Gün's translation received 22 reviews. Alev Adil's short piece, which was included in the present study as a review, was published as a response to Gün's response to Adil's and Ronald Wright's reviews of The New Life, which came out in 1997, three years after The Black Book was published.

43 Pamuk, The Black Book in Gün's translation, 176-77.

Vol. 9, n 1 | Fall 2017

"Translators and their Readers" 
${ }^{44}$ Pamuk, The Black Book in Freely's translation, 202.

45 Geoffrey N. Leech and Michael H. Short, Style in Fiction (London and New York: Longman, 1992 [1981]), 226.

${ }^{46}$ Ibid., 228.

${ }^{47}$ Esim Erdim, "The Survival of a Literary Text: The Transformation of Images from the Sublime to the Picturesque in Güneli Gün's Translation of Orhan Pamuk's Kara Kitap," (PhD diss., Kent State University, 1999), 181-82.

48 Pamuk, The Black Book in Gün's translation, 17.

${ }^{49}$ Erdim, “The Survival,” 181.

${ }^{50}$ Pamuk, Kara Kitap, 34.

51 Güneli Gün, “Something wrong with the language.” Times Literary Supplement 5006 (March 12, 1999): 14 .

52 Pamuk, The Black Book in Freely's retranslation, 20.

${ }^{53}$ Ibid., 19.

54 Ibid., 27.

${ }^{55}$ Freely, "Literary Translation," 5.

56 Alev Adil, “Translating Orhan Pamuk” TLS (March 26, 1999$): 17$.

57 Pamuk, The Black Book in Gün's translation, 23.

58 Pamuk, The Black Book in Freely's translation, 25.

${ }^{59}$ Leech and Short, Style in Fiction, 228.

${ }^{60}$ Giles Coren, "Genies We Lose in Translation." Review of The Black Book. The Times (August 3, 1995).

${ }^{61}$ Douglas Robinson, Translation and Empire: Postcolonial Theories Explained (Manchester: St. Jerome Pubishing, 1997), 111.

${ }^{62}$ Leech \& Short, Style in Fiction, 226.

${ }^{63}$ Lawrence Venuti, The Translator's Invisibility: A History of Translation, (London and New York: Routledge, 2012 [1995], 15.

${ }^{64}$ In their work, Douglas Robinson (Translation, 110-11) and Jean Boase-Beier (Stylistic, 6869) also discuss the relative nature of Venuti's concepts. 
${ }^{65}$ Gün, "Something Wrong with the Language," 14.

${ }^{66}$ Contrasting opinions about whether a translation is foreignizing or domesticating are not limited to the reviewers of The Black Book. Analysis reveals that there is disagreement, for instance, among the reviewers of Erdağ Göknar's English translation of Pamuk's My Name is Red as well. Lawrence Venuti quotes Richard Eder's review of My Name is Red, which Eder states is "translated with fluid grace" as evidence for "the dominance of fluency in Englishlanguage translation." Translator's Invisibility (London and New York: Routledge, 2008), 2, 3. However, the same translation is described as "woolly" and "stilted" by Adam Kirsch writing in the Washington Post. "Getting Real," Review of My Name is Red (September 2, 2001): BW 13. Please see Eker Roditakis, "Literary Journalism," for a detailed discussion on how reviews of translated literature approach the issue of translation.

${ }^{67}$ Smith, “Three Authors,” 1995.

${ }^{68}$ McGrath, "Dark,” 1995.

${ }^{69}$ McLemee, “One City’s Melancholy,” 2006.

70 When she took on the translation of Kara Kitap into English, Gün had written and published two novels in English in the US: Book of Trances (1979) and On the Road to Baghdad (1994).

${ }^{71}$ Gün, Interview by the author at The Cunda International Workshop for the Translators of Turkish Literature, 2007.

72 Pamuk, "Melancholy,” 2006.

\section{Bibliography}

Adams, Phoebe-Lou. Review of The Black Book. Atlantic Monthly 275, no. 2 (February 1995): 113-14.

Adil, Alev. “Alev Adil”. International Books of the Year. TLS December 5 (1997): 8.

17.

Barnacle, Hugo. Review of The Black Book. "Black as in Dull, Dark and Very, Very Dangerous." The Independent (July 22, 1995).

Berkers, Pauwke, Susanne Janssen, and Marc Verboord. "Contra-flows in Literary Journalism? Coverage of Foreign, Non-Western and Ethnic Minority Literatures in French, German, Dutch and American Newspapers, 1955-2005.” In The Invasion of Books in Peripheral Literary Fields: Transmitting Preferences and Images in the Media, Networks

Vol. 9, n 1 | Fall 2017

"Translators and their Readers" 
and Translation, edited by Petra Broomans and Ester Jiresch, 23-47. Groningen: Barkhuis, 2011.

Boase-Beier, Jean. Stylistic Approaches to Translation. Manchester: St. Jerome Publishing, 2006.

Bourdieu, Pierre. The Field of Cultural Production. Edited and introduced by Randal Johnson. Cambridge: Polity Press, 1993.

- "The Social Conditions of the International Circulation of Ideas." In Bourdieu: A Critical Reader, edited by Richard Shusterman, 220-28. Oxford: Blackwell Publishers, 1999.

Coe, Jonathan. "Up Against a Wall of Double Talk.” The Guardian (July 21, 1995).

Coren, Giles. Review of The Black Book. "Genies We Lose in Translation." The Times (August 3, 1995).

Eder, Richard. Review of The Black Book. "The Quest." Los Angeles Times Book Review (December 25, 1994).

Ekelund, Bo G., and Mikael Börjesson. "The Shape of the Literary Career: An Analysis of Publishing Trajectories.” Poetics 30 (2002): 341-64.

Eker Roditakis, Arzu. "Literary Journalism and Translation as Dynamics in the Recontextualization of Traveling Fiction: Orhan Pamuk's Pre-Nobel Novels in English and Their Reception in Reviews." PhD diss., Aristotle University of Thessaloniki, 2015.

- "The Identity Metonymics of Translated Turkish Fiction in English: The Cases of Bilge Karasu and Orhan Pamuk." In Tradition, Tension and Translation in Turkey, edited by Şehnaz Tahir Gürçağlar, Saliha Paker, and John Milton, 273-96. Amsterdam/Philadelphia: John Benjamins, 2015.

Erdim, Esim. “The survival of a Literary Text: The Transformation of Images From the Sublime to the Picturesque in Güneli Gün's Translation of Orhan Pamuk's Kara Kitap.” PhD diss., Kent State University, 1999.

Flower, Dean. Review of The Black Book. "A Fine and Private View." Hudson Review (1995): 485-92.

Freely, Maureen. Review of The Black Book. "Clues to a Maze." The Observer (June 25, 1995).

" "Maureen Freely: 'Literary Translation is a Literary Thing." Interview by Duygu Tekgül. Ceviribilim 04 (May-June 2011): 5. 
. Translator's Afterword. In The Black Book by Orhan Pamuk, 463-66. London: Faber and Faber, 2006.

Gün, Güneli. "Something Wrong With the Language.” Times Literary Supplement 5006 (March 12, 1999): 14.

Hadzibegovic, Darmin and Orhan Pamuk. Kara Kitap'in Sirlar Orban Pamuk'un Yą? ve Resimleriyle (The Secrets of Kara Kitap with Writings and Drawings by Orhan Pamuk). Istanbul: Yap1 Kredi Publications, 2013.

Heilbron, Johan. "Towards a Sociology of Translation: Book Translations as a Cultural World System.” European Journal of Social Theory 2, no. 4 (1999): 429-44.

Heilbron, Johan, and Gisele Sapiro. "Outline for a Sociology of Translation." In Constructing a Sociology of Translation, edited by Michaela Wolf and Alexandra Fukari, 93-107. Amsterdam, Philadelphia: John Benjamins Publishing, 2007.

Irwin, Robert. Review of The Black Book. "Tales of the City." TLS 4814 (July 7, 1995): 2.

Janssen, Susan. "Reviewing as Social Practice: Institutional Constraints on Critics' Attention for Contemporary Fiction.” Poetics 24 (1997): 275-97.

Koskinen, Kaise, and Outi Paloposki. "Retranslation." In Handbook of Translation Studies, edited by Yves Gambier and Luc van Doorslaer, 294-98. Amsterdam and Philadelphia: John Benjamins, 2010.

- "Retranslations in the Age of Digital Reproduction." Cadernos de Traducao 11 (2003): 19-38.

Leech, Geoffrey N., and Michael H. Short. Style in Fiction. London and New York: Longman, 1992 [1981].

Lefevere, André. "Mother Courage's Cucumbers." In Translation Studies Reader, edited by Lawrence Venuti, 233-49. London and New York: Routledge, 2000 [1982].

Translating Literature. New York: The Modern Language Association of America, 1992. "Why waste our time on rewrites? The Trouble with Interpretation and the Role of Rewriting in an Alternative Paradigm." In The Manipulation of Literature, edited by Theo Hermans, 215-243. London \& Sydney: Croom Helm, 1985. 
. "Why Waste Our Time on Rewrites? The Trouble with Interpretation and the Role of Rewriting in an Alternative Paradigm." In The Manipulation of Literature, edited by Theo Hermans, 215-43. London \& Sydney: Croom Helm, 1985.

McGaha, Michael. Autobiographies of Orhan Pamuk. Salt Lake City: University of Utah Press, 2008.

McGrath, Patrick. Review of The Black Book. "Dark and Fantastic Invention." The Washington Post (February 12, 1995).

McLemee, Scott. Review of The Black Book. "One City's Melancholy." Newsday (July 23, 2006).

Pamuk, Orhan. Kara Kitap. Istanbul: İletişim Publications, 2006 [1990].

—. The Black Book. Translated by Güneli Gün. London: Faber and Faber, 1995.

- The Black Book. Translated by Maureen Freely. London: Faber and Faber, 2006.

—. "The Melancholy Life of Orhan Pamuk." Interview by Joy E. Stocke, Wild Review Winter 2006, http://www.wildriverreview.com/1/wnt2006spotlight pamuk.html, accessed April 12, 2017.

—. Öteki Renkler: Seçme Yą̧lar ve Bir Hikaye. Istanbul: İletişim Publishing, 2006 [1999].

Pym, Anthony. Method in Translation History. Manchester: St. Jerome Publishing, 1998.

Robinson, Douglas. Translation and Empire: Postcolonial Theories Explained. Manchester: St. Jerome Pubishing, 1997.

Smith, Joan. Review of The Black Book. "Three Authors in Search of a Body." The Independent (August 13, 1995).

Stone, Judy. "Orhan Pamuk: Enigma is Sovereign." Publishers Weekly 241, no. 51 (December 19, 1994): 36-37.

Tahir Gürçağlar, Şehnaz. "Retranslation." In Routledge Encyclopedia of Translation Studies, edited by Mona Baker and Gabriela Saldanha, 233-36. London and New York: Routledge, 2009.

Toury, Gideon. "Culture Planning and Translation." In Anovar-anosar, estudios de traducción e interpretación (Vol. 1), edited by Alberto Alvarez Lugrís and Anxo Fernandez Ocampo, 13-26. Vigo: Universidade de Vigo, 1999. 
van Rees, Kees, and Jeroen Vermunt. "Event History Analysis of Authors' Reputation: Effects of Critics' Attention on Debutants' Careers.” Poetics 23 (1996): 317-33.

Venuti, Lawrence. "How to Read a Translation." Words Without Borders (July 2004). http://wordswithoutborders.org/article/how-to-read-

atranslation/\#ixzz1aIXq0qFI.

. "Retranslations: The Creation of Value." In Translation and Culture, edited by Katherine M. Faull, 25-38. Lewisburg: Bucknell University Press, 2004.

The Translator's Invisibility: A History of Translation. London and New York: Routledge, 2012 [1995].

Wright, Ronald. Review of The New Life. "From a Breeze-block Istanbul." Times Literary Supplement 4932 (October 10, 1997): 23. 